Primljen / Received: 8.6.2015. Ispravljen / Corrected: 27.7.2016.

Prihvaćen / Accepted: 23.2.2017. Dostupno online / Available online: 10.8.2018.

\section{Use of e-plastic waste in bituminous pavements}

Author:

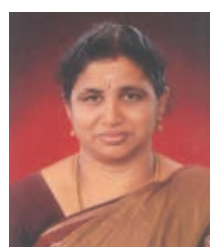

Prof. Lakshmi Murugan, PhD. CE

Kamaraj College of Engineering and Technology Department of Civil Engineering

Tamil Nadu, India

lakshmiciv@gmail.com

\section{Lakshmi Murugan}

\section{Use of e-plastic waste in bituminous pavements}

This paper presents the research conducted on the samples of traditional asphalt mixes and asphalt mixes with plastic granules as replacement for coarse aggregate. Marshall stability parameters of these mixes are compared to determine an optimum proportion of plastic granules. The objective was to determine whether plastic components obtained by e-waste recycling can be used in pavement structures. The research was conducted in the scope of the plan for accountable management of increasingly growing quantities of e-waste.

Key words:

e-waste, sustainability, recycling, pavements, bitumen

Stručni rad

\section{Lakshmi Murugan}

\section{Primjena plastike iz elektroničkog otpada u asfaltnim kolnicima}

U radu je prikazano istraživanje provedeno na uzorcima tradicionalnih asfaltnih mješavina i mješavina asfalta s dodatkom granula plastike kao zamjene za krupni agregat. Uspoređene su vrijednosti Marshallove stabilnosti asfaltnih mješavina s ciljem određivanja optimalnog udjela granula plastike. Cilj je bio utvrditi postoji li mogućnost da se u kolnicima primjene plastične komponente dobivene recikliranjem elektroničkog otpada, što se izvodi u sklopu plana za odgovorno gospodarenje elektroničkim otpadom, kojeg u posljednje vrijeme ima sve više.

Ključne riječi:

elektronički otpad, održivost, recikliranje, kolnici, bitumen

Fachbericht

\section{Lakshmi Murugan}

\section{Verwendung von Kunststoff aus Elektronikschrott im Asphaltbelag}

In der Abhandlung wird die Untersuchung dargelegt, die an Proben traditioneller Asphaltmischungen und Asphaltmischungen mit dem Zusatz von Kunststoffgranulat als Ersatz für großes Aggregat durchgeführt wurde. Verglichen wurden die Werte der Marshall-Stabilität der Asphaltmischungen mit dem Ziel, den optimalen Anteil des Kunststoffgranulats festzulegen. Das Ziel war es festzustellen, ob die Möglichkeit besteht, in den Fahrbahnen Kunststoffkomponenten zu verwenden, die aus wiederverwertetem Elektronischschrott gewonnen wurden, was im Rahmen des Plans der verantwortungsvollen Entsorgung von Elektronikschrott, wovon es in letzter Zeit immer mehr gibt, durchgeführt wird.

Schlüsselwörter:

Elektronikschrott, Nachhaltigkeit, Wiederverwertung, Fahrbahnen, Bitumen 


\section{Introduction}

The magnificent developments of the electronic world have improved the quality of modern society. At the same time, the associated issues include the massive quantity of obsolete electronic gadgets, waste categories, and a substantial amount of hazardous waste generated from electrical and electronic products. These wastes constitute a great threat to the human health and environment. Administration of these squanders with a strategic approach requires coordinated efforts to develop a process for achieving sustainable waste management.

E-waste management is a burgeoning global issue, which showcases the repercussions of such waste on humans and the environment. Effective waste management strategies have to be developed, with a special emphasis on recycling options. Global environmental activities evolve with the augmentation of living and non-living resources and their related social activities. The generation of e-waste and its pollution possibilities relates the environmental problems with the electronic and electrical industries. According to the United Nations Environment Program, 20 to 25 million tonnes of electronic waste are produced worldwide each year [1]. According to prediction by ABI Research, by 2017 the volume of discarded e-products is expected to increase worldwide by 33 percent compared to 2012, and would weigh about eight times the equivalent weight of the Great Pyramids of Egypt.

Journal of Environmental Science \& Technology (2012) has foreseen that the production of e-waste by developing countries will exceed by at least two times that of developed countries within the next 6-8 years. It predicts that in 2030, developing countries will discard 400 million - 700 million obsolete personal computers per year, which is comparatively higher compared to developed countries.

A report submitted by the United Nations predicts that, by 2020, e-waste from old computers would increase by 400 percent when compared to 2007 figures in China, and would reach a 500 percent increase in India. In addition, it is reported that e-waste derived from obsolete mobile phones would be more than seven times greater than the 2007 figures in China and in India, while about 18 times increase is predicted by 2020 [2]. This forecast imposes the need to place an immediate and high focus on the management of electronic waste in developing nations like India, where strategic plan to regulate the recycling process needs to be established, with an appropriate relevance to societal reforms.

Non - Governmental Organisations (NGOs) such as Toxics Link actively supervise harmful and hazardous substances in the Indian context. The mentioned organization reports on generation of Waste Electrical and Electronic Equipment (WEEE) in India, points to recycling sectors in the country, and provides reviews based on toxicity of these waste streams [3]. The major focus is on the ecological and economical assessment of processes in industrial sectors.
"Recycling from E-Waste to Resources", a report issued at a meeting of Basel Convention, used data from 11 representative developing countries and estimated the current and future e-waste generation [4]. According to the report, the generation of global e-waste is growing by about 40 million tons a year. It is expected that, by the year 2020, e-waste generated from televisions will be 1.5 to 2 times higher in China and India, while in India the e-waste from discarded refrigerators will be double or triple. Furthermore, with the same year of observation it is predicted that in China, e-waste from discarded mobile phones will be about 7 times greater and in India even 18 times greater than the stature of 2007. These facts reveal the immense attention to be conferred to the preparation of an effective waste management plan for the dumped e-waste and all sorts of its components.

\subsection{Material composition of e-waste}

There are more than 1000 different toxic substances in e-waste, such as lead, mercury, cadmium, selenium, hexavalent chromium, etc. Amongst them, the predominant ones are ferrous metals, non-ferrous metals, precious metals, glass, plastics, etc. A graphical representation of material fractions in electronic waste is presented in Figure 1.

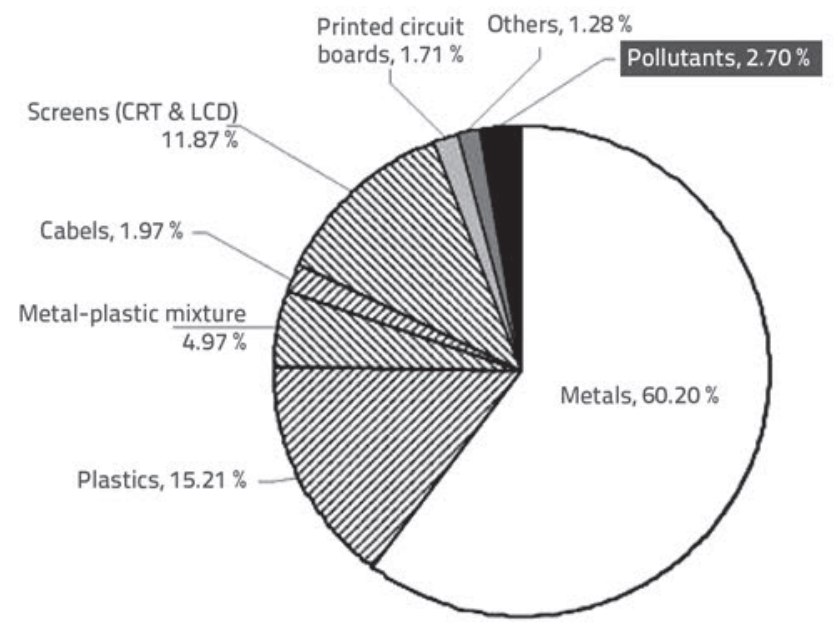

Figure 1. Material Fractions in e-waste [5]

In many townships, the non-reusable e-waste materials pose a problem in the solid waste disposal process. These non-reusable e-waste materials are landfilled, which curtails bio-degradation and thereby affects the environment. Waste Electronic and Electrical Equipment (WEEE) is composed of varied components. It is of great importance to characterize the waste stream to develop a cost effective and eco-friendly recycling system [6]. Separation processes for various e-waste components are outlined in Figure 2.

Specially designed plastics form an integral part of the communications and electronics industry. They are designed in the form of circuits printed on boards and as accessory elements 
in the manufacture of computer chips. To recycle plastics from discarded electronics, the order of actions must be devised to enable recovery of materials for reuse, namely metals and plastic components. The process of elementary cutting and crushing operations applied to plastic components results in the generation of particles of preferred size for downstream recycling applications.

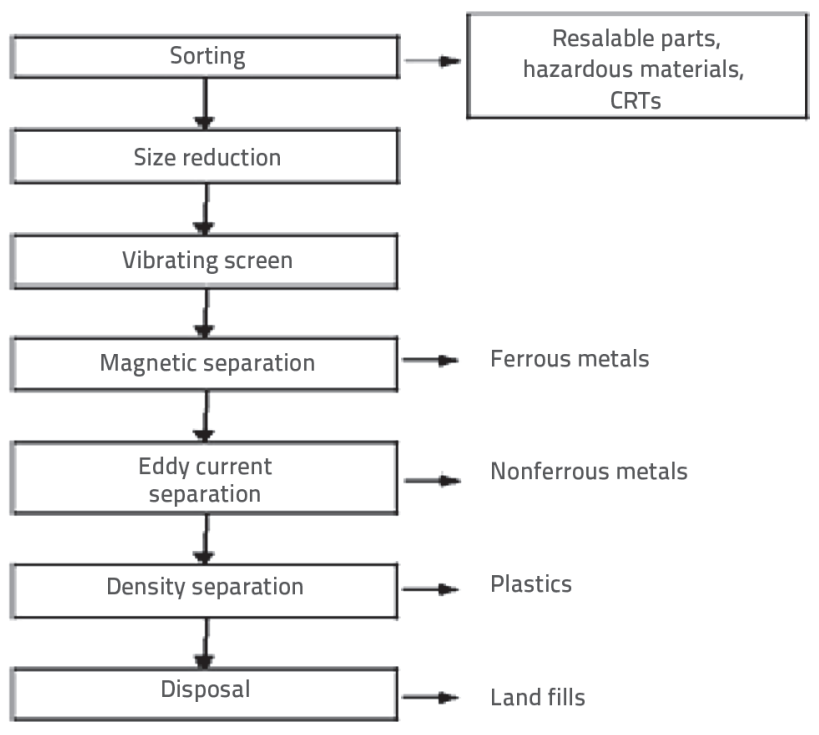

Figure 2. Diagram of e-waste-materials recovery plan [7]

According to the Plastics information home page, alpha butadiene styrene (ABS), a harder and high-quality plastic, is substituted for metals in the fabrication of CPU and keyboard housings. In addition to ABS plastics, the major category of resins used in computers and televisions includes high Impact polystyrene (HIPS), polyphenylene oxide (PPO), etc.

\subsection{Environment Impacts of e-waste}

Toxic materials involved in the manufacture of electronic gadgets are the main reason for the environmental pollution caused by obsolete electronic objects [8]. Ministry of Environment and Forest (MOEF) guidelines issued in 2008 specify that e-waste contains numerous types (more than 1000 varieties) of substances and chemicals creating serious human health and environment problems [9].

The most common method of managing e waste is landfilling, and it has become common information that all landfills leak. Even the best "state of the art" ones are not completely sealed throughout their lifetime, and a certain amount of chemical and metal leaching will occur. The situation is far worse for older ones or less stringently controlled dumpsites. The vaporization of metallic mercury and dimethylene mercury must also be taken into consideration. Uncontrolled fires may be initiated at such landfills, posing additional environmental and health risks. Landfilling is the most common method of managing e-waste, which also results in chemical and metal leaching. In many developing countries, most of the e-waste is incinerated in the backyard and this practice eventually results in uncontrolled fires that are harmful to environment [10].

In many developing countries where e-waste recycling is conducted through informal recycling sectors, most of the e-waste is improperly handled and much of it is incinerated by backyard recyclers to recover valuable metals like gold. These informal practices release steady plumes of far reaching toxic pollution and yield very low metal recovery rates compared to the state of the art industrial facilities [11]. The toxic constituents and their components are given in Table 1.

Table 1 Toxic Constituents of WEEE Categories (According to the EU Directive on WEEE)

\begin{tabular}{|c|c|}
\hline Constituents & Components \\
\hline Lead and cadmium & Printed circuit boards \\
\hline Mercury & Switches and flat screen monitors \\
\hline Cadmium & Computer batteries \\
\hline PCB & Capacitors and transformers \\
\hline Brominated flame retardant & Printed circuit boards, plastic \\
casings cable
\end{tabular}

A varied fraction of reusable components is used in the refining and conditioning processes. These processes sometimes involve the use of strong acids. Children and women are included in the operations and the usage of acids is likely to affect their health seriously. Environmental hazards are also considerable, which is not considered as a major factor in these sites. After extraction of valuable part of e-waste, the remaining scraps of no money value are left as dumps, and are further subjected to backyard extraction, which sometimes results in toxic emissions [11].

In densely populated regions, people are forced to work in odd working environments with exposure to poor ventilation, dangerous chemicals, etc. Many of the participants are not attentive to the apparent risks and safe work practices [12]. Kurian Joseph addressed the issue of e-waste management in India. In his paper, a major focus is on the lack of civil sense and awareness, unhealthy conditions of recycling, and inadequate legislation incapable of harnessing the ever growing electronic waste. The author recommended implementation of the Extended Producer Responsibility (EPR) policy approach as a means to reduce generation of waste [13].

\subsection{Recycling options for e-waste}

It is essential to landfill e-squanders like heavy metals, glass, plastics, ferrous and non-ferrous metals, and toxic matters that are very harmful, and to adopt the $4 \mathrm{R}$ concept (reduce, reuse, recover and recycle) so as to minimise e-waste hazards. 
However, landfilling is still a non-recyclable practice, as biodegradation is sometimes not enabled and, in such cases, landfills do not offer an environmentally friendly solution.

New recycling and recovery processes have to be developed. An excessive presence of certain elements such as lead, cadmium, mercury, and arsenic, etc., in e-waste leads to a categorization as hazardous waste. The key aspect in developing a mechanical recycling system is to enable an effective segregation of these elements.

The flow of precious metals like silver, gold, platinum, palladium, etc. is one of key economic drivers of Material Recovery Facilities (MRFs). The concentrations of these valuable components create strong interest to recover these material fractions. The plastic recycling processes involve shredding, separation, and palletisation techniques. The recycling techniques have been adopted as a basic process to reach an eco-friendly disposal suggestion for plastic constituents of the e-squander.

Recycled plastics are sorted into constituent types using vast amount of manpower at high processing costs. However, recycling of waste ensures environmental protection. The incorporation of plastics into building materials reduces material requirements and also curbs the problem of disposing the plastics. Presently, plastics that are recycled are sorted into constituent types, and then melted down before they can be reused. This requires vast amount of manpower and processing costs. Consequently, a small portion of consumed plastics is recycled, while the remaining large quantity is dumped at landfills. There is a pressing requirement to find a method to reuse plastics without extensive efforts and excess costs. In addition, recycling of waste in bulk volume should be a preferred waste management strategy aimed at minimising problems related to the disposal of waste.

The use of plastics as a building material presents dual advantages: first, the requirement for materials is reduced and, second, the waste plastics - which presents an ever increasing disposal problem - is thus recycled without further encumbering waste treatment and storage facilities [14].

The source material dictates the process of recycling waste electric and electronic equipment. Generally, WEEE must be cut into small and even fine-sized particles. Mechanical separation plays an important role in WEEE recycling. Kenneth Stier and Gray Weede report that plastic granules extracted from greeting card racks were used in concrete after being cut using plastic granulator of app. > 0.010" to 0.030" in diameter and one inch in length. It has been confirmed that concrete containing recycled plastics fibre showcases promising results with regard to its compression, tension, and flexure [15].

According to published research results, rheological properties and quality of bitumen are influenced by mixing in polymeric compounds such as rubber and plastics. Aslam reports that bitumen modified by adding waste plastic in about $5-10 \%$ weight proportion improves the strength and durability characteristics of pavement [16]. Blending synthetic polymers like rubbers and plastics modifies rheological properties of bitumen, and thereby enhances its quality. This improved bitumen enhances the longevity and performance of pavement. The mixture of bitumen and polymer forms a suitable substitute material for smooth pavement construction as it has higher values of Marshall Stability and Marshall Coefficient [17].

Justo and Veeraragvan concluded that the addition of $8.0 \%$ by weight of processed plastic results in modified bituminous concrete (BC) mixes exhibiting improved strength and stability parameters [18]. The combination of recycled Low Density Polyethylene (LDPE) and asphalt protects the building from ageing. The use of plastics enhances mix properties and helps in reducing voids while also delaying formation of potholes [19]. Yue Hang observed that 15 to $30 \%$ of aggregates can be replaced with properly recycled LDPE particles, which also positively influence the longevity and performance of asphalt pavements [20]. The mixing of asphalt with recycled LDPE can be operated using usual equipment and practices, and requires no alternative techniques [21].

The recycled plastic components of e-squander are referred to as e-plastic particles. This study focusses on the use of plastic components of e-waste as partial replacement for coarse aggregate. The use of e-plastic particles in the preparation of modified bitumen mixes is proposed. The performance of modified mixes is analysed based on Marshall stability indices.

\section{Experimental programme}

The application of recycled e-plastic particles in pavements offers an attractive solution for managing the requirement in coarse aggregate, and is also an effective waste management approach associated with the disposal of biologically nondegradable plastics into the environment. Pellets prepared from recycled plastics were used in bituminous mixes as partial aggregate replacement $[22,23]$.

An experimental investigation on the use of waste plastic particles obtained from scrap e-waste in bituminous mixes is carried out in this study. The utilization of waste plastic particles as partial replacement of coarse aggregate in bituminous mixes is in the focus of the research reported in this paper. Various combinations of plastic bound bituminous mixes were designed to determine the range of recycling applications of waste plastics. The observed properties of e-plastic particles are presented in Table 2.

Table 2. Physical Characteristics of Waste e-plastic particles

\begin{tabular}{|c|c|}
\hline Properties & E-plastic particle \\
\hline Specific gravity & 1.01 \\
\hline Absorption & $<0.2 \%$ \\
\hline Colour & white and dark \\
\hline Shape & angular \\
\hline Crushing value & $<2 \%$ \\
\hline Impact value & $<2 \%$ \\
\hline
\end{tabular}


Bitumen penetration grade of $60 / 70$, which is harder than $80 / 100$ and withstands a greater traffic load, is used [24]. The characteristics of this grade correspond to those of $\mathrm{S}$ 65 grade of IS-73-2006 and IS-1208-1978. Laboratory test results of bitumen used in this investigation are presented in Table 3.

Table 3. Characteristics of Bitumen used in this study

\begin{tabular}{|c|c|}
\hline Tests & Results \\
\hline Softening point & $46.3^{\circ} \mathrm{C}$ \\
\hline Ductility & $58 \mathrm{~cm}$ \\
\hline Penetration at $25^{\circ} \mathrm{C}$ & $67 \mathrm{~mm}$ \\
\hline
\end{tabular}

\subsection{Mix classification}

The description of items according to "Specifications for Road and Bridgeworks" issued by the MORTH (Ministry Of Road Transport \& Highway), Government of India, and published by the Indian Road Congress(IRC) is adopted in this investigation. The aggregate percentage specified by the MORTH and adopted in this study is given below:

- $10 \%$ aggregate $11.2 \mathrm{~mm}$ (120 g)

- $70 \%$ aggregate $6.7 \mathrm{~mm}$ (840 g)

- $20 \%$ quarry dust ( $240 \mathrm{~g}$ )

Various mixtures adopted in this study are presented in Table 4.

\subsection{Test procedure}

Three compacted samples were prepared for each of the four binder contents. The course aggregate, fine aggregate, and filler material, were proportioned in accordance with requirements specified in relevant standards. The resistance of the prepared bituminous mixture is estimated using Marshall test.

Marshall specimens were prepared as per guidelines given in ASTMD 1559. The height and diameter of the bituminous mixture specimens were $63.5 \mathrm{~mm}$ and $101.5 \mathrm{~mm}$, respectively. Approximately 1200 gm of good quality crushed stone coarse aggregates and plastic particles were prepared as aggregate to serve the purpose of replacement material. The bitumen heating temperature was maintained between $140^{\circ} \mathrm{C}$ and $160^{\circ} \mathrm{C}$, and the recycled plastic was added to aggregate at specified percentage. The required amount of bitumen as per the desired trial percentage was added to the mixed aggregate, and then the complete mixture was thoroughly blended.

The modified bitumen mixture was kept in a mould. After 24 hours of setting, the specimen was removed from the mould. After some time, the specimen was immersed in hot water at the temperature of $60^{\circ} \mathrm{C}$ for 30 minutes. Finally, the specimen was taken out of the water bath and the water was wiped off. The prepared specimen was placed in the Marshall Testing machine. Then the Marshall stability value, flow value, and unit weight of the specimen, were determined. The maximum force recorded during compression testing was registered as Marshall stability value (kN), and the relevant deformation as flow vale. The stiffness of the mixture was reported as Marshall Quotient (MQ in kN/mm). It is an indicative measure of the resistance of pavement to permanent deformation.

\section{Results and discussion}

Mixtures were prepared using bituminous contents in the proportion varying from $4.5 \%$ to $6 \%$. An optimum binder content, with maximum compacted mix density and maximum stability, was obtained during the experiment. Marshall test

Table 4. Mix specifications

\begin{tabular}{|c|c|c|c|c|}
\hline MIX ID & $\begin{array}{l}\text { Coarse aggregate } \\
\text { Particle size } 11.2 \mathrm{~mm}\end{array}$ & $\begin{array}{l}\text { Coarse aggregate } \\
\text { Particle size } 6.7 \mathrm{~mm}\end{array}$ & $\begin{array}{l}\text { Plastic aggregates - weight } \\
\text { percent of } 6.7 \mathrm{~mm} \text { aggregate }\end{array}$ & Quarry dust \\
\hline $\begin{array}{c}\text { Mix CB } \\
10: 70: 0: 20\end{array}$ & $10 \%-120 g$ & $70 \%-840 g$ & $0 \%$ & $20 \%-240 g$ \\
\hline $\begin{array}{c}\text { Mix PB1 } \\
\text { 10:66:4:20 }\end{array}$ & $10 \%-120 g$ & $66 \%-792 g$ & $4 \%-48 g$ & $20 \%-240 g$ \\
\hline $\begin{array}{c}\text { Mix PB2 } \\
10: 62: 8: 20\end{array}$ & $10 \%-120 g$ & $62 \%-744 g$ & $8 \%-96 g$ & $20 \%-240 g$ \\
\hline $\begin{array}{c}\text { Mix PB3 } \\
\text { 10:58:12:20 }\end{array}$ & $10 \%-120 g$ & $58 \%-696 g$ & $12 \%-144 g$ & $20 \%-240 g$ \\
\hline $\begin{array}{c}\text { Mix PB3 } \\
\text { 10:54:16:20 }\end{array}$ & $10 \%-120 g$ & $54 \%-648 g$ & $16 \%-192 g$ & $20 \%-240 g$ \\
\hline
\end{tabular}

Table 5. Marshall test results - control mix (Mix CB)

\begin{tabular}{|c|c|c|c|c|}
\hline $\begin{array}{c}\text { Binder content by weight of } \\
\text { aggregate }[\%]\end{array}$ & $\begin{array}{c}\text { Unit weight } \\
{\left[\mathrm{kg} / \mathrm{m}^{3}\right]}\end{array}$ & Stability $[\mathrm{kN}]$ & Marshall stability values & $\begin{array}{c}\text { Marshall quotient } \\
{[\mathrm{kN} / \mathrm{mm}]}\end{array}$ \\
\cline { 3 - 5 } & 2398.00 & 12.97 & 2.26 & 5.74 \\
\hline 4.5 & 2403.33 & 13.42 & 2.53 & 5.30 \\
\hline 5 & 2413.53 & 14.02 & 2.86 & 4.90 \\
\hline 5.5 & 2398.02 & 13.47 & 3.38 & 3.98 \\
\hline
\end{tabular}


Table 6. Marshall test results - Mix PB1 (4\% plastic bituminous mix)

\begin{tabular}{|c|c|c|c|}
\hline \multirow{2}{*}{$\begin{array}{c}\text { Binder content by weight of } \\
\text { aggregate [\%] }\end{array}$} & $\begin{array}{c}\text { Unit weight } \\
{\left[\mathrm{kg} / \mathrm{m}^{3}\right]}\end{array}$ & \multicolumn{2}{|c|}{ Marshall stability values } \\
\cline { 3 - 4 } & 2404.23 & 17.77 & 2.34 \\
\hline 4.5 & 2412.57 & 21.33 & 2.52 \\
\hline 5 & 2416.33 & 23.65 & 2.59 \\
\hline 5.5 & 2411.63 & 21.82 & 8.76 \\
\hline 6 & & & 2.99 \\
\hline
\end{tabular}

Table 7. Marshall test results - Mix PB2 (8\% plastic mix)

\begin{tabular}{|c|c|c|c|c|}
\hline $\begin{array}{c}\text { Binder content by weight of } \\
\text { aggregate [\%] }\end{array}$ & $\begin{array}{c}\text { Unit weight } \\
{\left[\mathrm{kg} / \mathrm{m}^{3}\right]}\end{array}$ & 2385.57 & 18.69 & \multicolumn{2}{|c|}{$\begin{array}{c}\text { Marshall stability values } \\
{[\mathrm{kN} / \mathrm{mm}]}\end{array}$} \\
\cline { 3 - 5 } & 2392.39 & 24.32 & 3.35 \\
\hline 4.5 & 2392.72 & 27.41 & 3.72 \\
\hline 5 & 2391.78 & 22.82 & 4.06 \\
\hline 6.5 & & 6.75 & 4.61 \\
\hline
\end{tabular}

Table 8. Marshall test results - Mix PB3 (12\% plastic mix)

\begin{tabular}{|c|c|c|c|c|}
\hline \multirow{2}{*}{$\begin{array}{c}\text { Binder content by weight of } \\
\text { aggregate }[\%]\end{array}$} & \multirow{2}{*}{$\begin{array}{l}\text { Unit weight } \\
{\left[\mathrm{kg} / \mathrm{m}^{3}\right]}\end{array}$} & \multicolumn{2}{|c|}{ Marshall stability values } & \multirow{2}{*}{$\begin{array}{l}\text { Marshall quotient } \\
{[\mathrm{kN} / \mathrm{mm}]}\end{array}$} \\
\hline & & Stability [kN] & Flow $[\mathrm{mm}]$ & \\
\hline 4.5 & 2388.08 & 23.60 & 3.57 & 6.61 \\
\hline 5 & 2397.58 & 28.21 & 4.18 & 6.75 \\
\hline 5.5 & 2406.32 & 36.35 & 5.01 & 7.25 \\
\hline 6 & 2411.63 & 26.57 & 5.29 & 5.02 \\
\hline
\end{tabular}

Table 9. Marshall test results - Mix PB4 (16\% plastic mix)

\begin{tabular}{|c|c|c|c|c|}
\hline \multirow{2}{*}{$\begin{array}{c}\text { Binder content by weight of } \\
\text { aggregate }[\%]\end{array}$} & \multirow{2}{*}{$\begin{array}{l}\text { Unit weight } \\
{\left[\mathrm{kg} / \mathrm{m}^{3}\right]}\end{array}$} & \multicolumn{2}{|c|}{ Marshall stability values } & \multirow{2}{*}{$\begin{array}{c}\text { Marshall quotient } \\
{[\mathrm{kN} / \mathrm{mm}]}\end{array}$} \\
\hline & & Stability [kN] & Flow $[\mathrm{mm}]$ & \\
\hline 4.5 & 2368.08 & 21.56 & 3.51 & 6.14 \\
\hline 5 & 2361.22 & 25.04 & 3.80 & 6.58 \\
\hline 5.5 & 2370.15 & 26.90 & 4.10 & 6.56 \\
\hline 6 & 2361.37 & 20.87 & 2.95 & 7.07 \\
\hline
\end{tabular}

results for control mix and PB mixes in which coarse aggregate was partly replaced with plastic particles are described in Tables 5 to 9.

Marshall test results for the conventional mix with various binder contents are presented in Table 5. The results indicate that the stability values vary for various binder contents by weight of aggregates. The unit weight increases only marginally with an increase in binder content. The stability of all the values increases with an increase in binder content. For the control bitumen mix, the optimum binder content for achieving optimum Marshall indices was observed to be $5.5 \%$ by weight of aggregates, which agrees with previous investigations. Table 6 describes Marshall test results for mix PB ( $4 \%$ plastic bituminous mix) with various binder content.
Mix PB 1 results indicate that, just like in control mix, the unit weight, Marshall stability and flow values increase with an increase in binder content. With $4 \%$ plastic particles as aggregate replacement in bitumen mix, stability values are nearly $60 \%$ higher compared to the control mix. In addition, for the $4 \%$ plastic bitumen mix, the optimum binder content for achieving maximum Marshall indices amounts to $5.5 \%$ by weight of aggregates.

Marshall test results for mix PB 2 ( $8 \%$ plastic bituminous mix) with various binder contents are presented in Table 7. For 8 $\%$ plastic bitumen mix, the test results indicate that - with 8 $\%$ weight replacement of coarse aggregates by plastics - the Marshall stability values increase by nearly $70 \%$ compared to the conventional bitumen mix. In addition, for the $8 \%$ plastic 
bitumen mix, the optimum binder content for achieving maximum values of Marshall indices was observed to be $5.5 \%$ by weight of aggregates.

Marshall test results for mix PB 3 ( $12 \%$ plastic mix) with various binder contents are shown in Table 8.

Test results for the $12 \%$ plastic bitumen mix show that the Marshall stability values range from $23.60 \mathrm{kN}$ to $36.35 \mathrm{kN}$ for various binder contents. With an increase in weight of plastic particles as weight percent of coarse aggregate, the Marshall stability and flow values also increase by about $140 \%$ compared to the conventional bitumen mix.

Marshall test results for mix PB 4 ( $16 \%$ plastic mix) with various binder contents are shown in Table 9. Test results for the 16 $\%$ plastic bitumen mix show that the Marshall stability values actually decline compared to the $12 \%$ PB mix. However, when compared to the conventional mix, the $16 \%$ PB mix reveals an average $74.5 \%$ increase in stability indices.

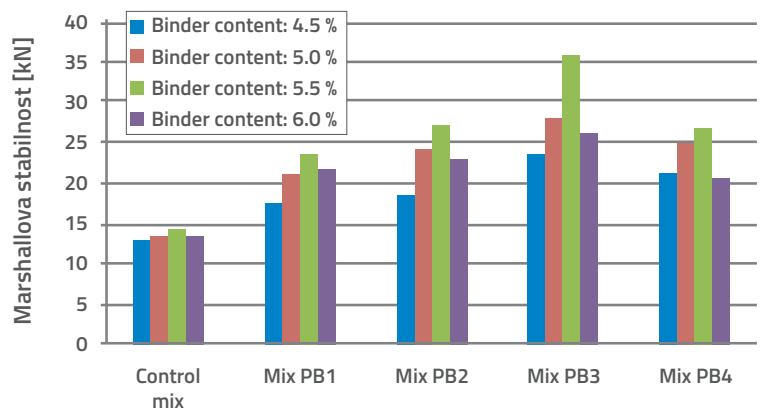

Figure 3. Variation of Marshall Stability values of Plastic Bitumen mixes

The variation of Marshall stability vs binder content is shown in Figure 3. Marshall test results were obtained for various mixes with varying binder content by weight of aggregate $(4.5 \%, 5.5 \%$, and $6 \%$ ). E-waste plastic particles were substituted in all these binder contents as weight percentage of coarse aggregate varying from $0 \%, 4 \%, 8 \%, 12 \%$ and $16 \%$. The maximum stability value was observed at $5.5 \%$ binder content both in conventional and plastic bitumen mixes, which correlates with previous investigations. Hence, an optimum binder content for desired mixes as per MORTH specification amounted to $5.5 \%$. Compared to conventional bitumen mix, the PB 3 mix shows a $159 \%$ increase in Marshall stability, which is a very significant observation in the study.

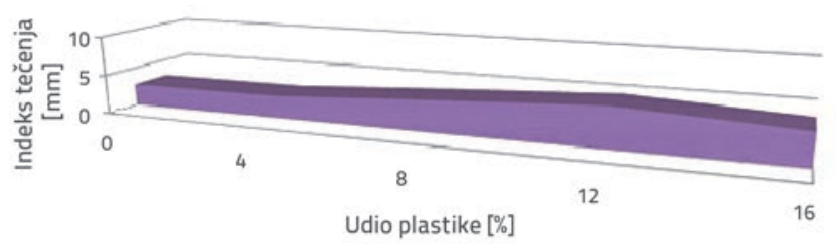

Figure 4. Variation of flow values for plastic bitumen mixes at optimum binder content
According to Figure 4, flow values observed for plastic bitumen mixes show that the maximum flow occurs at PB3 mix, which is limited to a maximum value of $5 \mathrm{~mm}$. Depending on the high flow values, the mixes were observed to be sturdy and flexible. Dispersion of plastic particles at higher replacement percentages is identified to be the factor influencing the flow of mixes. Conversely, the lower flow value is exhibited at mix PB4 which has a higher plastic content in this series.

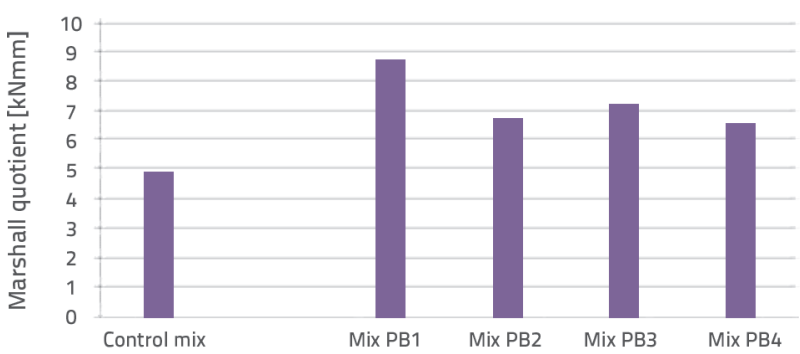

Figure 5. Percentage of Plastic particles Vs Marshall Quotient

The influence of plastic particles on the Marshall Quotient of bituminous mixes is shown in Figure 5. It can be observed that the plastic particle substituted bituminous mixes produce higher MQ values when compared to the control mix. Higher MQ values ensure the resistance of bituminous pavement against shear failure, permanent warping failure, and pothole failure, which agrees with the findings of Sinan and Agar [26].

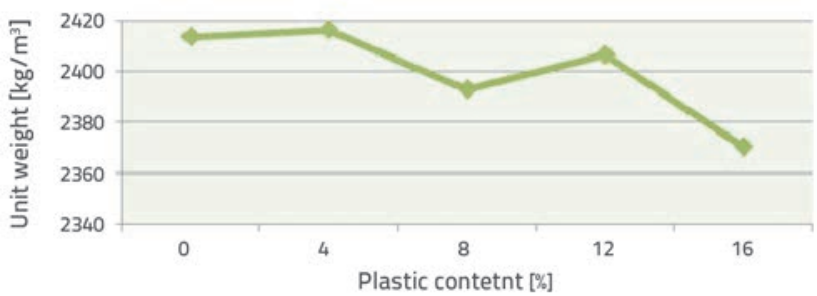

Figure 6. Variation of unit weight of plastic bitumen mixes at optimum binder content

The effect of plastic particles on unit weight of the modified bituminous mix is plotted in Figure 6 for the desired optimum binder content of $5.5 \%$. It is apparent that the unit weight declines with an increase in plastic content in bituminous mixes. Eventually, the lesser weight plastic particles are found to influence the unit weight of plastic mixes. Mix PB4 with higher percentage of plastic content shows a $92 \%$ increase in stability value when compared to the conventional mix CB.

\section{Conclusion}

The disposal of the End-of-Life (EOL) electronic products creates a major environmental threat owing to hazardous content and rapidly growing volume of such products. Based on the investigation presented in the paper, the following conclusions have been reached about the effect of e-plastic waste utilization in bituminous mixes: 
- Previous studies were conducted to explore the possibility of using waste glass and plastic as aggregate in concrete. In line with these findings, it was observed that e-plastic waste can be substituted as an aggregate replacement material.

- Based on particle size analysis, it was established that e-plastic particles can be used for partial replacement of aggregate in bituminous pavements. The waste plastic particles were introduced in bituminous mixes as percentage weight replacement of coarse aggregate.

- Based on Marshall Stability parameters, it was established that an optimum binder content amounts to $5.5 \%$, which corresponds to the results of previous investigations $[17,28]$.

- It was observed that the flow value increases with an increase in the content of plastic material. However, the lower binder ratio kept the flow value at minimum despite the plastic content in the mixes.

- Marshall stability, flow values, and Marshall quotient, increase considerably, compared to the conventional bitumen mix, with an increase in weight of plastic particles used as replacement material by weight percent of coarse aggregate in the bituminous mixes. $12 \%$ plastic bitumen mix results in maximum Marshall stability, which is approximately three times higher than the conventional bitumen mix. Rasel recommended that scrap polyvinyl chloride (PVC) available from domestic and commercial waste can be utilized in bituminous mixes when up to $10 \%$ in weight proportion of bitumen is added [28].

- The higher range of flow values and Marshall quotient of plastic-particle substituted mixes indicate that the mixes were elastic and also stronger.

- The use of e-plastic particles as aggregate replacement in the bitumen mix seems feasible, which also fulfils the objective of this study. This recycling option of using e-waste plastic particles in bituminous pavements is associated with manifold benefits of designing a recycling system that is cost effective, conserves natural resources, and uses waste in an environmentally benign manner.

\section{REFERENCES}

[1] United States Environment Protetion agency (USPEA):, Electronic reuse and recycling infrastructure development in Masschusetts, EPA-901-R-00-002, (2000).

[2] United Nations Environment Programme, 2010, UN News Centre, Urgent need to prepare developing Countries for surge in E-waste, Document ID:612, Article ID 6471.

[3] Toxics Link. E-waste in Chennai, 2004.

[4] Sodhi, M.S., Reimer, B.: Basel Action Network, UNEP Environment Alert Bulletin, 1-4, January 2005.

[5] Empa, The E-waste guide:2005, http://www.ewaste.ch.

[6] Cui, J., Forssberg, E.: Mechanical recycling of waste electric and electronic equipment: a review, Journal of Hazardous Materials, B99 (2003), pp. 243-263, https://doi.org/10.1016/S03043894(03)00061-X

[7] Hai-Yong K., Schoenung, J.M.: Electronic waste recycling: A review of U.S. infrastructure and technology options", Resources Conservation \& Recycling, 45 (2005), pp. 368-400, https://doi. org/10.1016/j.resconrec.2005.06.001

[8] Mehta, P.K., Monteiro, P.M.: Concrete: Structure, Properties, and Materials, Prentice Hall, 549, 1993.

[9] MoEF guidelines for Environmentally Sound Management of E-waste, 2008.

[10] Toxics Link, 2004, E-waste in Chennai, www.toxicslink.org

[11] Wang, F., Kuehr, R., Ahlquist, D., Li, J.: E-waste in China: a country report. Bonn, Germany, United Nations University, 2013.

[12] Toxics Link. Scrapping the hi-tech myth, computer waste in India, Delhi, 2008.

[13] Kurian, j.: Electronic waste management in India-Issues and Strategies, Proceedings Sardinia 2007, Eleventh International Waste Management and Landfill Symposium, pp. 1-5, 2007.
[14] Subramanian, P.M.: Plastics recycling and waste management in the US, Resources, Conservation and Recycling, 28 (2000), pp. 253-263, https://doi.org/10.1016/S0921-3449(99)00049-X

[15] Stier, K.W., Gray Weede, D.: A Study Conducted to Investigate the Feasibility of Recycling Commingled Plastics Fibre in Concrete, Journal of Industrial Technology, 15 (1999) 1, pp. 1-8.

[16] Shahan-ur-Rahman, A.: Use of Waste Plastic in Construction of Flexible Pavement, New Building Materials \& Construction World, 2009.

[17] Vasudevan, R.: Utilization of waste plastics for flexible pavement, Indian High Ways Indian Road Congress, 7 (2006).

[18] Justo, C.E.G., Veeraragavan, A.: Utilization of Waste Plastic Bags in Bituminous Mix for Improved Performance of Roads, Centre for Transportation Engineering, Bangalore University, Bangalore, India, 2002.

[19] Rema devi, M., Leni, S., Mini, M.l.: Reduction of optimum bitumen content in bituminous mixes using plastic coated aggregates, International journal of innovative research in science, engineering \& technology, 2 (2013) 3, pp. 698-705.

[20] Yue Huang, Roger, N. Bird, Heidrich, O.: A review of the use of recycled solid waste materials in asphalt pavements, Resources, Conservation and Recycling, 52 (2007), pp. 58-73, https://doi. org/10.1016/j.resconrec.2007.02.002

[21] FHWA, User guidelines for waste and by-product materials in pavement construction, 1997 .

[22] Zoorob, S.E., Suparma, L.B.: Laboratory design and investigation of the properties of continuously graded Asphaltic concrete containing recycled plastics aggregate replacement (Plastiphalt), Cement \& Concrete Composites, 22 (2000), pp. 233-242, https:// doi.org/10.1016/S0958-9465(00)00026-3 
[23] Jain, R.K., Singh, Y., Rai, M.: Recent Trends of Research in Plastic Building materials in India, Building and Environment, 12 (1977), pp. 277-280, https://doi.org/10.1016/0360-1323(77)90030-0

[24] Vasudevan, R.: Utilization of Waste Polymers for Flexible Pavement and Easy Disposal of Waste Polymers, Proceedings of the International Conference on Sustainable Solid Waste Management, 5 - 7 September 2007.

[25] MORTH, Ministry of Road, Transport and Highways, Specifications for Road and Bridgeworks, Third Revision, Published by Indian Road Congress, 2000
[26] Hinishoglu, S., Agar, E.: Use of high density polyethylene as bitumen modifier in asphalt concrete mix, Materials Letters, 58 (2004), pp. 267-271, https://doi.org/10.1016/S0167-577X(03)00458-0

[27] Al-Abdul Wahhab, H., Al-Amri, G.: Laboratory evaluation of reclaimed rubber asphaltic concrete mixes, Journal of Materials in Civil Engineering, 3(1991), pp. 189 - 197, https://doi.org/10.1061/ (ASCE)0899-1561(1991)3:3(189)

[28] Rasel, H.M., Rahman, M.N., Ahmed, T.U.: Effect of waste PVC on the properties of Bituminous mixes, International Journal of Civil Engineering, 4 (2012) 1, pp. 77-84. 